\title{
Effect of Instructional Scheme for Patients undergoing liver transplantation Surgery on Their Performance
}

\author{
Prof. Dr. Mohamed Abd El- wahab Ali ${ }^{1}$, Prof. Dr. Amany M. Shebl Abed El-Lateef ${ }^{2}$, \\ Ass. Prof. Dr. Shereen Ahmed Ahmed Qalawa ${ }^{3}$, and Eman Mohammed Helmiey El- \\ Shafiey ${ }^{4}$. \\ ${ }^{1}$ Prof of Gastrointestinal Surgery- Faculty of Medicine, Mansoura University; ${ }^{2}$ Prof of \\ Adult Nursing- Dean of- Faculty of Nursing, Mansoura University; ${ }^{3}$ Assistant Professor \\ of Medical - Surgical Nursing, Faculty of Nursing - Port Said University; \\ ${ }^{4}$ Clinical Instructor, Mansoura University, Egypt.
}

\begin{abstract}
Background: liver transplantation (LT) is a lifesaving procedure for patients with chronic end-stage liver disease and acute liver failure. Aim of the study: was to evaluate the effect of instructional scheme for patients undergoing liver transplantation surgery on their performance. Materials and Method: A quasi- experimental research design was used to conduct this study. A convenient sample of patients who were scheduled for liver transplantation surgery through 6 months from the beginning of June 2014 to the end of November 2014, they were (30) patients, who were attended from liver transplantation unit and out- patient's (clinic) in Gastro Enterology Center at Mansoura University. Three main tools were used to collect data; 1) - Socio demographic and patient heath history sheet, 2) - Pre/ post knowledge assessment questionnaire sheet, and 3) - patient's practices sheet. Results: a significant statistical difference was found in relation to the total and subtotal mean knowledge scores during different assessment periods with $\mathrm{P}$ value $<0.05^{*} \&$ a significant statistical difference was found in relation to the total and subtotal mean practice scores during post implementation periods at $\mathrm{P}$ value $<0.05^{*}$. Conclusion: Liver transplantation patients showed an improvement in their knowledge and practice scores. This improvement was manifested in their immediately and after instructional scheme implementation total and subtotal mean knowledge and practice scores. Recommendations: All patients who are scheduled for liver transplantation and their families are in need to an adequate knowledge and practices to help them to adapt with their life after transplantation. Further studies have to be carried out in order to assess nurse's knowledge and practices regarding care of liver transplantation. Replication of the study on a large probability sample selected from different geographical areas to obtain generalized data.
\end{abstract}

Key words: Liver transplantation, Performance, Instructional Scheme. 


\section{INTRODUCTION}

Liver transplantation (LT) is the replacement of a diseased liver with some or all of a healthy liver from another person (allograft). The most commonly used technique is orthotopic transplantation, in which the native liver is removed and replaced by the donor organ in the same anatomic location as the original liver. Liver transplantation is available treatment option for end stage liver disease, acute liver failure, and early liver tumors in cirrhotic livers (Abd El-hakeem, 2014\& El-Gamal et al, 2013).

Liver transplantation recipients and graft survival rates has improved dramatically since the inception of the liver transplantation life-saving procedure. With the achievement of 5- year, 10- year patient and graft survival at 70.60 and $67 \%$ respectively. The overall improvement of health related quality of life could occur during the first year post transplant and may be sustained(Mabrouk et al, 2012).

Teaching the patient with liver transplantation and family about long term measures to promote health is crucial for the success of transplantation and is an important role of the nurse (Smeltzer et al, 2010 \& Kruzik, 2009\& Mendes and Galvao, 2008). Patients who need solid organ transplantation suffer from a chronic condition, which by itself entails risks and health problems. Thus, patients who are capable of understanding the transplantation can also change their living experience. They need to learn how to deal with new drugs, take them for the rest of their lives, besides adhering to lifestyle changes, including hygiene practices, infection prevention, monitoring of the new organ's functioning, body image changes, adaptation to mood and energy level swings, professional issues among others (Duma, 2012).

Patients understand that they must perform respiratory exercises to prevent pneumonia, how to use the incentive spirometer; and the movement is imperative for preventing blood clots, encouraging circulation to the extremities, and keeping the lungs clear; they will be much more likely to perform these tasks. In addition, pre-operative teaching is a vital part of nursing care. Studies have shown that pre-operative teaching reduces patient's anxiety and post-operative complications (Kaltsakas et al, 2013 \& Mendes et al, 2013).

\section{Significance of the Study:}

Over 6000 people receive a liver transplant in the United States each year; more than 1600 patients are listed (Busuttil and Klintmalm, 2015).

In Egypt, there is no doubt that chronic liver diseases are a major health concern. Hepatitis $C$ virus prevalence among the 15 - 59 years age group is estimated to be $14.7 \%$. Accordingly there are thirteen liver transplantation centers in Egypt. By the end of June 2014, the total number of cases reached 2,406. This number comprised 2,246 adult cases (93\%) and160 pediatric cases $(7 \%)$. The vast majority of indications were hepatitis $\mathrm{C}$ virus (64\%) and (26\%) for hepatocellular carcinoma (Amer and Marwan, 2016).

Furthermore, the statistical reports in Gastro Enterology Center at Mansoura University in Egypt revealed that, the number of (LDLT) cases is increasing and reached 
to 419 cases from 2004 to December 2015.

\begin{abstract}
Aim of the study:
The aim of this study was to evaluate the effect of instructional scheme for patients undergoing liver transplantation surgery on their performance as indicated by: pre and post- operative knowledge and practice mean scores, in Gastro Enterology Center at Mansoura University.
\end{abstract}

\title{
Research Hypotheses:
}

- Patients undergoing liver transplantation who will be exposed to the designed instructional scheme will show better outcomes as regards to their knowledge scores.

- Patients undergoing liver transplantation who will be exposed to the designed instructional scheme will show better outcomes as regards to their practice scores.

\section{Materials and Methed:}

(I)- Technical Design: includes; research design, setting, subjects, and tools of data collection.

\section{Research Design:}

A quasi-experimental research design was used for the conduction of this study.

\section{Setting:}

The study was carried out at liver transplantation unit and out- patient's (clinic) in Gastro Enterology Center at Mansoura University.

\section{Subjects:}

The subjects of the study were patients who were scheduled for liver transplantation surgery through 6 months from the beginning of June 2014 to the end of November 2014. They were (30) patients and attending liver transplantation unit in Gastro Enterology Center at Mansoura University and fulfilling the inclusion criteria; Adult aged from (2160 ) years old, male and female, and accept to participate in the study.

\section{Tools of data collection:}

Three main tools were used for data collection:

Tool (1): Socio demographic and patient heath history sheet; was developed to assess sociodemographic data, (past, present and family history) for studied subjects.

It comprised of two main parts:

The first part: - socio demographic data : was developed by the researcher, composed of (seven) multiple choice questions including age, sex, marital status, residence, educational level, occupation, and working effort.

The second part: - Patients health history: was developed to assess the past, the present and the family history for studied subjects. It was adapted from (Mohammed et al, 2014) as follows: 
- Past and present health history, which were composed of (six) closed ended questions including, type of chronic illness, causes of developing hepatic failure, time of developing hepatic failure, drugs used before transplantation, smoking habits, and relative degree with the donors.

- Family health history, which was composed of (three) closed ended questions including, family history of liver diseases, the degree of relativity, and family history of liver transplantation.

Tool (2): - Pre/ post knowledge assessment questionnaire sheet: developed by the researcher, based on reviewing related literature as (El-Gamal et al, 2013), to assess patient's knowledge about liver transplantation. It consisted of (seventeen) multiple choice questions, which was divided into (nine) parts as follows: general knowledge about liver transplantation, complications of liver transplantation, follow up after liver transplantation, medications after liver transplantation, infection hazards after liver transplantation, daily practices, nutrition, physical exercises, and exposure to sun.

\section{Scoring system of Knowledge questionnaire sheet:}

Knowledge questionnaire sheet consisted of 17 multiple choice questions, each point is scored 0 for incorrect answer and 1 for correct answer and the total knowledge score is 85. Total patients' knowledge score was divided into the following levels similar to previous study conducted by (El-Gamal et al, 2013) who considered:

- Scores less than 51(<60\%) are considered as unsatisfactory.

- From 51-68 (60\%-80\%) are considered as satisfactory.

- From $68-85(>80 \%)$ are considered as good.

Tool (3): patient's practices sheet: was observational checklists adopted from (Abou Shehata et al, 2012), to assess patients practices that applied by the patient post operatively. It consisted of (four) sections with (fourty eight) items, to assess patients ability to practice different exercises as deep breathing and coughing exercises (5 items), inspiratory muscle training technique (incentive spirometer) (6 items) range of motion exercises (37 items) for: head and neck (6 items), stretching exercises for upper extremities (4 items), stretching exercises for lower extremities ( 8 items), strengthening exercises for upper arm muscles ( 8 items), strengthens ankle and calf muscles (5 items), and strengthens thigh and hip muscles(6 items).

\section{Scoring system of observational checklists:}

Checklist is an assessment tool for recording patient's performance for different exercises. Each correct item in the checklist got one score for done and 0 for not done items with a total scores of 48 . Then, it is divided into the following levels similar to previous study conducted by (El-Gamal et al, 2013) who considered:

- Scores less than $29(<60 \%)$ are considered as unsatisfactory.

- From 29-38 (60\%-80\%) are considered as satisfactory.

- From 38-48 (>80\%) are considered as good.

\section{(II)- Operational Design:}

The operational design of this study included preparatory phase, content validity, pilot study, and field work. 


\section{Preparatory Phase:}

It included reviews of current and post local and international related literatures, and theoretical knowledge of various aspects of the study using books, articles, and internet periodicals and magazines in order to develop the data collection tools.

\section{Content Validity and Reliability:}

The researcher designed an opinnionnaire sheet to test the content validity of the health outcomes sheet by a jury including five experts in the field of medical surgical nursing and surgery, faculties of nursing Port-said and Mansoura universities and faculty of medicine Mansoura University to measure the validity. It involved two parts:

a-The opinions of the experts for each item were recorded on a two point scale: relevant, not relevant and clear, not clear.

b- General or overall opinion about the form, they were requested to express their opinions and comments on the tool and provide any suggestions for any additional or omissions of items. Then necessary modifications were done. This phase was carried out in a period of one month.

Testing reliability: of knowledge assessment tool was done by cronbachs alpha test. Its value was $(0.682),(\mathrm{P}=0.000)$ which indicated moderate reliability.

\section{Pilot study:}

A pilot study was carried out on four patients. The main purpose for the pilot study were to test the clarity, feasibility of the tools and whether it was understandable, and to determine the time needed to fill the tool. The tool was handed to participants to fill it and collected by researcher.

\section{Field Work:}

The study was implemented through 9 months from the beginning of June 2014 to February 2015, through the following four phases:

Phase I: Prior instructional scheme development: Based on the information obtained from pilot study, in addition to literature, the researcher designed the instructional program. It included the following items: brief description of liver and liver transplantation (definition, causes, complications, symptoms of rejection, and drugs needed). Health Instructions needed for liver transplantation related to (respiration and keeping the chest clear, drug taking, infection control measures, general health care and daily routine, nutrition, daily activities, and sun ray exposure). The instructional booklet was written in simple Arabic language with different illustrated colored pictures to enhance the learning process and facilitate patients understanding.

Phase 2: Pre-test phase (prior instructional scheme implementation): after preparing the tool, the researcher interviewed the patients in the liver transplantation unit after introducing herself and took the consent of them to be recruited in the study after explaining the aim of the study and then distributed the pre- tested questionnaire sheet after clear explanation of the way 
to fill out. The researcher used tools; (1) socio demographic data and medical health sheet and tools ( $2 \& 3)$ knowledge and practices that required after liver transplantation before operation. Then the patients were asked to write down their answers. Confidentiality for all collected information was strictly assured.

Phase 3: Implementation phase: The scheme given for each patient alone according to the patient who was selected for operation. The program was conducted through three sessions; each session took about two hours. The total allocated time for achieving the whole scheme for the 30 patients were 180 hours (30patients $\times 6$ hours). Different teaching and learning methods were used during the sessions which included; interactive lecture, discussion, demonstration $\&$ re demonstration, instructional media included pictures, and printed handout which was presented in clear and concise form to be used as memorial reference and using a very simple slang language that suits the level of patients. Patients were allowed to ask any interpretation, elaboration or explanation of any item included in the sessions. The duration of program implementation was six months (from first of June 2014 till the end of November 2014).

Phase 4: Evaluation phase (post-test\& follow- up tests): the effect of implementing the instructional scheme on the patients performance was evaluated by the researcher in 2 times; immediately after the instructional scheme implementation (immediate posttest) by using tools ( 2 and3), and after 3 months from instructional scheme implementation (follow-up) in the outpatient in Gastro Enterology Center at Mansoura University or by phone, by using tools ( 2 and 3 ). The results were compared to the pretest results. The duration of evaluation phase was six months (from first of September 2014 till the end of February 2015).

\section{(III)- Ethical Consideration:}

All relevant ethical aspects were considered for ensuring patients privacy and confidentiality of the collected data during the study. The purpose of the study was explained to each patient, and then an oral consent for participation in the study was obtained from each one of them. Voluntary participation and right to refuse to participate in the study and withdrawn at any time was emphasized to patients.

\section{(IV)- Statistical Design:}

The collected data were organized, tabulated and statistically analyzed using statistical package for social science (SPSS) version 15, running on IBM compatible computer. Descriptive statistics were applied (e.g. mean, standard deviation SD, frequency, and percentage). Test of significance was performed to test the study hypotheses i.e. Paired Samples Test (P-value).

\section{Significance of results was as the following:}

- When $\mathrm{P}>0.05$ there was no statistically significant differences.

- When $\mathrm{P} \leq 0.05$ there was statistically significant differences.

- When $\mathrm{P}<0.001$ there was highly statistically significant differences. 


\section{RESULTS:}

Table (1): showed that the mean age of the studied subjects were $49.97 \pm 5.50$ as $56.6 \%$ were more than or equal to 50 years old. Males were more prevalent than females; they constituted $86.6 \%$ of the studied subjects. Regarding the marital status, the sample percent $93.3 \%$ were married. Also, $53.3 \%$ of the studied subjects were lived in rural areas. $43.3 \%$ of the studied subjects had universal education while $13.3 \%$ were not able to read and write. Finally $76.6 \%$ of the studied subjects were working, and $23.3 \%$ were not working.

Table (2): showed that, $46.66 \%$ of the studied subjects were had chronic diseases; diabetes mellitus was the most common disease among the subjects it was reported by the majority $64.28 \%$ of the studied subjects. Hepatitis C virus, bilhariziasis, liver cancer, fatty liver, auto immune diseases, and gall stones reported by the nearest percent as the cause of developing liver failure $86.66 \%, 50.00 \%, 13.33 \%, 3.33 \%, 3.33 \%$, and $3.33 \%$. In relation to the medications were taken before liver transplantation, it was observed that $36.66 \%$ of the subjects were previously taken medications before liver transplantation. $93.33 \%$ from the studied subjects were on relative degree with the donor.

Table (3): showed that, more than half of the studied subjects $56.66 \%$ had family history of liver failure, while all of them not have family history of liver transplantation.

Table (4): demonstrated higher total and subtotal post mean knowledge scores regarding knowledge about liver transplantation, complications, medications, infection control measures, daily practices, nutrition, physical exercises, exposure to sun, and follow up after liver transplantation throughout the study periods as compared to their preimplementation score, with significant statistical difference at the following $\mathrm{P}$ value $(<$ $\left.0.05^{*}\right)$.

Table (5): showed that, all of the study subjects $100 \%$ had unsatisfactory level of knowledge before implementation of the instructional scheme, while $30.0 \%$ had satisfactory level of knowledge immediately after implementation of the scheme, while $40.0 \%$ had good level of knowledge after 3 months from implementation of the scheme.

Table (6): demonstrated higher total and subtotal post mean practice scores regarding deep breathing and coughing exercises, using incentive spirometer, range of motion exercises, and breast self-examination during post implementation periods with significant statistical difference at the following $\mathrm{P}$ values $\left(<0.05^{*}\right)$.

Table (7): showed that, $96.7 \%$ of the study subjects had unsatisfactory level of practices score before implementation of the instructional scheme, while $70.0 \%$ had satisfactory level of practice immediately after implementation of the scheme, and $76.7 \%$ had good level of practice after 3 months from implementation of the scheme.

Figure (1): showed that, $91.3 \%$ of studied subjects were needed moderate effort and $8.69 \%$ need strong effort during working. 
Figure (2): illustrated that, $71.42 \%$ of the studied subjects were in the first degree of relativity with their donors and $28.57 \%$ were in the second degree.

Figure (3): revealed that $81.80 \%$ of the studied subjects were taken interferon as the treatment before liver transplantation; however $18.18 \%$ were taken chemotherapy.

Table (1): Distribution of the Studied Subjects According to their Socio-demographic Characteristics $(\mathrm{n}=30)$ :

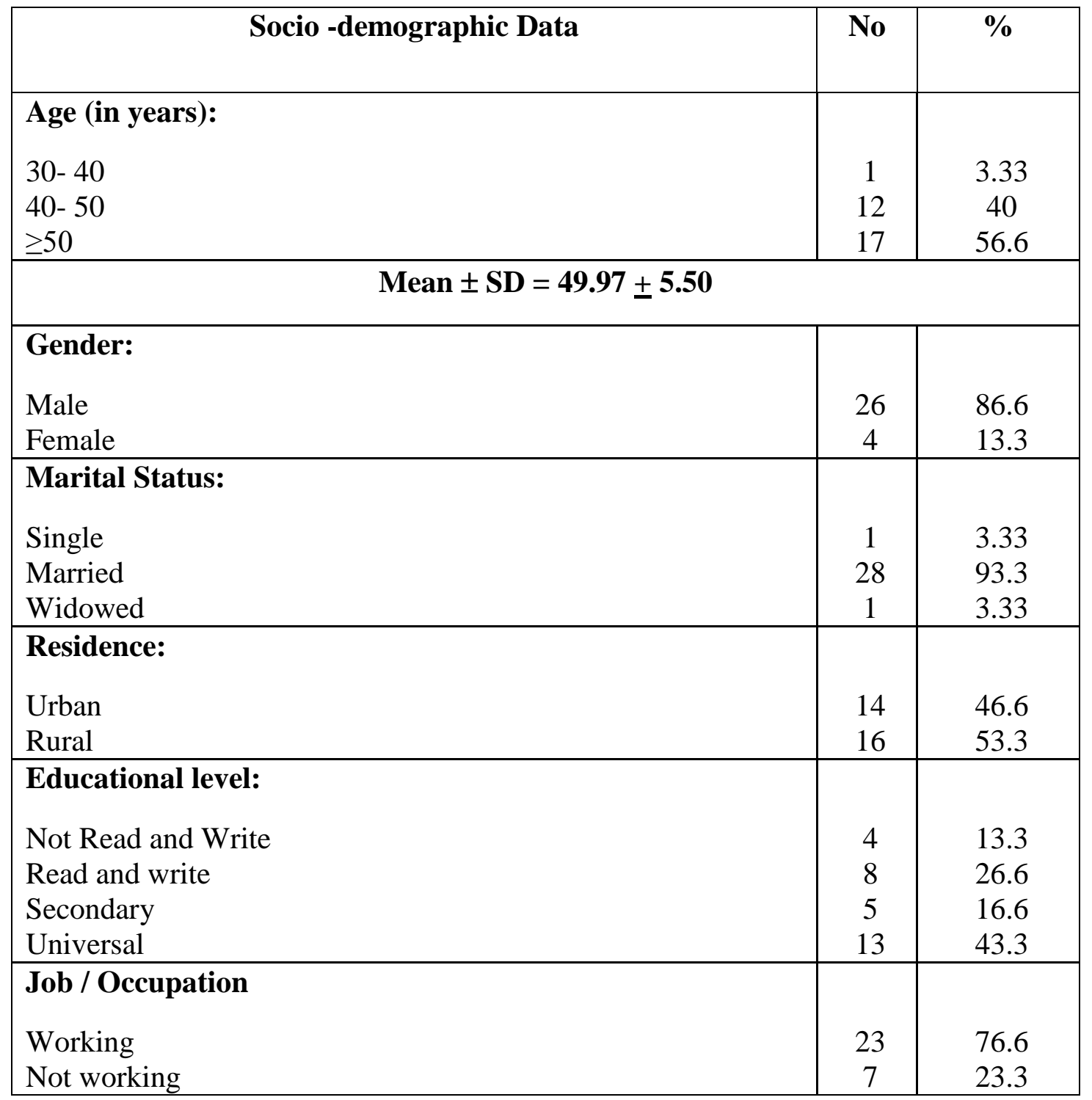


Table (2): Distribution of the Studied Subjects According to their Past and Present Health History $(\mathrm{n}=30)$ :

\begin{tabular}{|l|c|c|}
\hline \multicolumn{1}{|c|}{ Past and Present Health History } & N & \% \\
\hline Chronic diseases: & & \\
Yes & 14 & 46.66 \\
No & 16 & 53.33 \\
\hline *Disease type: & & \\
Diabetes mellitus & 9 & 64.28 \\
Hypertension & 3 & 21.42 \\
Osteoporosis & 2 & 14.28 \\
\hline C Causes of developing liver failure: & & \\
Hepatitis C & 26 & 86.66 \\
Bilhariziasis & 15 & 50.00 \\
Liver cancer & 4 & 13.33 \\
Fatty liver & 1 & 3.33 \\
Auto immune diseases & 1 & 3.33 \\
Gall stones & 1 & 3.33 \\
\hline Medications before liver transplantation: & & \\
Yes & 11 & 36.66 \\
No & 19 & 63.33 \\
\hline Smoking: & & \\
Yes & 1 & 3.33 \\
No & 17 & 56.66 \\
Previous & 12 & 40.00 \\
\hline Relative degree with the donor: & 28 & 93.33 \\
Yes & 2 & 6.66 \\
No & & \\
\hline No" & & \\
\hline
\end{tabular}

N.B: *" Answers were not mutually exclusive".

Table (3): Distribution of the Studied Subjects According to their Family History ( $\mathrm{n}=$ 30):

\begin{tabular}{|l|c|c|}
\hline \multicolumn{1}{|c|}{ Family history } & N & $\%$ \\
\hline Family history of liver failure: & & \\
Yes & 17 & 56.66 \\
No & 13 & 43.33 \\
\hline *Degree of relativity: & & \\
First degree & 16 & 94.11 \\
Second degree & 1 & 5.88 \\
\hline *Family history of liver transplantation: & 17 & \\
No & & 100 \\
\hline
\end{tabular}

N.B: *" Answers were not mutually exclusive". 
Table (4): Distribution of the Studied Subjects According to Total and Subtotal Mean Knowledge Scores throughout the Study Periods $(n=30)$ :

\begin{tabular}{|c|c|c|c|c|}
\hline $\begin{array}{l}\text { Assessment period } \\
\text { Items }\end{array}$ & $\begin{array}{c}\text { Pre (IS) } \\
\text { Mean } \pm \text { SD }\end{array}$ & $\begin{array}{c}\text { Immediately } \\
\text { after (IS) } \\
\text { Mean+SD } \\
\end{array}$ & $\begin{array}{l}\text { After (IS) } \\
\text { Mean } \pm \text { SD }\end{array}$ & $\begin{array}{c}\text { P- } \\
\text { values } \\
\text { (P1\&P2) } \\
\end{array}$ \\
\hline $\begin{array}{l}\text { Knowledge about liver } \\
\text { transplantation. }\end{array}$ & $1.80 \pm 0.81$ & $3.83 \pm 1.23$ & $4.67 \pm 1.12$ & $<0.05^{*}$ \\
\hline $\begin{array}{l}\text { Complications after } \\
\text { liver transplantation. }\end{array}$ & $0.90 \pm 1.06$ & $5.33 \pm 1.37$ & $7.30 \pm 1.18$ & $<0.05^{*}$ \\
\hline $\begin{array}{l}\text { Medications after liver } \\
\text { transplantation. }\end{array}$ & $2.17 \pm 1.82$ & $11.13 \pm 2.96$ & $14.80 \pm 2.91$ & $<0.05^{*}$ \\
\hline $\begin{array}{ll}\text { Infection } & \text { control } \\
\text { measures. } & \\
\end{array}$ & $4.27 \pm 2.30$ & $10.03 \pm 2.46$ & $12.53 \pm 1.96$ & $<0.05^{*}$ \\
\hline $\begin{array}{l}\text { Daily practices after } \\
\text { liver transplantation. }\end{array}$ & $0.37 \pm 0.85$ & $3.77 \pm 1.41$ & $5.67 \pm 1.03$ & $<0.05^{*}$ \\
\hline $\begin{array}{l}\text { Nutrition after liver } \\
\text { transplantation. }\end{array}$ & $1.33 \pm 1.63$ & $8.90 \pm 2.20$ & $11.83 \pm 1.58$ & $<0.05^{*}$ \\
\hline $\begin{array}{lr}\text { Physical } & \text { exercises } \\
\text { after } & \text { liver } \\
\text { transplantation. } & \\
\end{array}$ & $1.00 \pm 0.87$ & $2.73 \pm 0.91$ & $3.63 \pm 0.81$ & $<0.05^{*}$ \\
\hline Exposure to sun. & $1.00 \pm 0.87$ & $3.17 \pm 0.87$ & $4.27 \pm 0.69$ & $<0.05^{*}$ \\
\hline $\begin{array}{l}\text { Follow up after liver } \\
\text { transplantation. }\end{array}$ & $1.13 \pm 0.43$ & $3.57 \pm 1.10$ & $4.50 \pm 0.68$ & $<0.05^{*}$ \\
\hline Total (85) & $13.97 \pm 6.98$ & $52.47 \pm 10.86$ & $69.20 \pm 7.82$ & $<0.05^{*}$ \\
\hline
\end{tabular}

* Significant at the $\mathbf{P}<\mathbf{0 . 0 5}$ probability level

Table (5): Total knowledge Score among Studied Subjects throughout Different Study Periods $(n=30)$ :

\begin{tabular}{|l|c|c|c|c|c|c|}
\hline \multicolumn{1}{|c|}{ Score Levels } & \multicolumn{2}{c|}{$\begin{array}{c}\text { Unsatisfactory } \\
\text { Assessment Periods }\end{array}$} & \multicolumn{2}{c|}{$\begin{array}{c}\text { Satisfactory } \\
\mathbf{6 0 0}\end{array}$} & \multicolumn{2}{c|}{$\begin{array}{c}\text { Good } \\
>80 \%\end{array}$} \\
\hline \multirow{2}{*}{ Before implementation } & 30 & 100 & - & - & - & - \\
\cline { 2 - 7 } & 18 & 60.0 & 9 & 30.0 & 3 & 10.0 \\
\hline Immediately after implementation & 1 & 3.3 & 17 & 56.7 & 12 & 40.0 \\
\hline Three months post implementation & & $\mathbf{N}$ & $\mathbf{N}$ & $\%$ \\
\hline
\end{tabular}


Table (6): Total and Subtotal Mean Practice Scores throughout the Study Periods ( $\mathrm{n}=$ 30):

\begin{tabular}{|l|c|c|c|c|}
\hline \multicolumn{1}{|c|}{ Assessment periods } & $\begin{array}{c}\text { Pre (IS) } \\
\text { Mean } \pm \text { SD }\end{array}$ & $\begin{array}{c}\text { Immediately } \\
\text { after (IS) } \\
\text { Mean } \pm \text { SD }\end{array}$ & $\begin{array}{c}\text { After (IS) } \\
\text { Mean } \pm \text { SD }\end{array}$ & $\begin{array}{c}\text { P- values } \\
\text { (P1\&P2) }\end{array}$ \\
\hline $\begin{array}{l}\text { Items } \\
\text { coughing exercises. }\end{array}$ & $0.13 \pm 0.57$ & $2.80 \pm 0.81$ & $4.33 \pm 0.71$ & $<0.05^{*}$ \\
\hline $\begin{array}{l}\text { Using incentive } \\
\text { spirometer. }\end{array}$ & $1.27 \pm 1.44$ & $3.67 \pm 0.99$ & $5.10 \pm 0.84$ & $<0.05^{*}$ \\
\hline Range of motion exercises: & $2.17 \pm 1.09$ & $4.23 \pm 0.82$ & $5.40 \pm 0.77$ & $<0.05^{*}$ \\
Head and neck exercises. & $2.13 \pm 1.85$ & $8.67 \pm 1.32$ & $10.20 \pm 0.96$ & $<0.05^{*}$ \\
Stretching exercises. & $2.37 \pm 2.55$ & $12.23 \pm 2.67$ & $15.17 \pm 2.25$ & $<0.05^{*}$ \\
Strengthening exercises. & $8.07 \pm 5.13$ & $31.60 \pm 4.74$ & $40.20 \pm 3.84$ & $\mathrm{p} 1>0.05$ \\
& & & & $\mathrm{p} 2<0.05^{*}$ \\
\hline Total (48) & & & & \\
\hline
\end{tabular}

$\boldsymbol{P 1}$ is statistical significant deference between pre and immediately phase.

$\boldsymbol{P 2}$ is statistical significant deference between immediately and post phase.

Table (7): Practices Score Levels among Study Subjects throughout the Study Periods $(n=30)$ :

\begin{tabular}{|c|c|c|c|c|c|c|}
\hline $\begin{array}{l}\text { Score Levels } \\
\text { Assessment Periods }\end{array}$ & \multicolumn{2}{|c|}{$\begin{array}{c}\text { Unsatisfactory } \\
<60 \%\end{array}$} & \multicolumn{2}{|c|}{$\begin{array}{c}\text { Satisfactory } \\
60-80 \%\end{array}$} & \multicolumn{2}{|c|}{$\begin{array}{l}\text { Good } \\
>80 \%\end{array}$} \\
\hline & $\mathbf{N}$ & $\%$ & $\mathbf{N}$ & $\%$ & $\mathbf{N}$ & $\%$ \\
\hline Before implementation & 29 & 96.7 & 1 & 3.3 & - & - \\
\hline Immediately after implementation & 8 & 26.7 & 21 & 70.0 & 1 & 3.3 \\
\hline Three months post implementation & - & - & 7 & 23.3 & 23 & 76.7 \\
\hline
\end{tabular}


Figure (1): Distribution of the Studied Subjects According to their Working effort $(\mathrm{n}=$ 23).

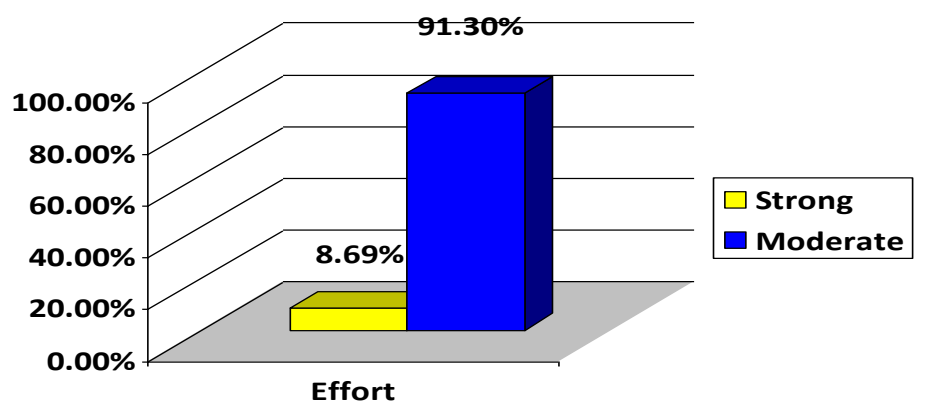

Figure (2): Degree of Relativity with the Donors:

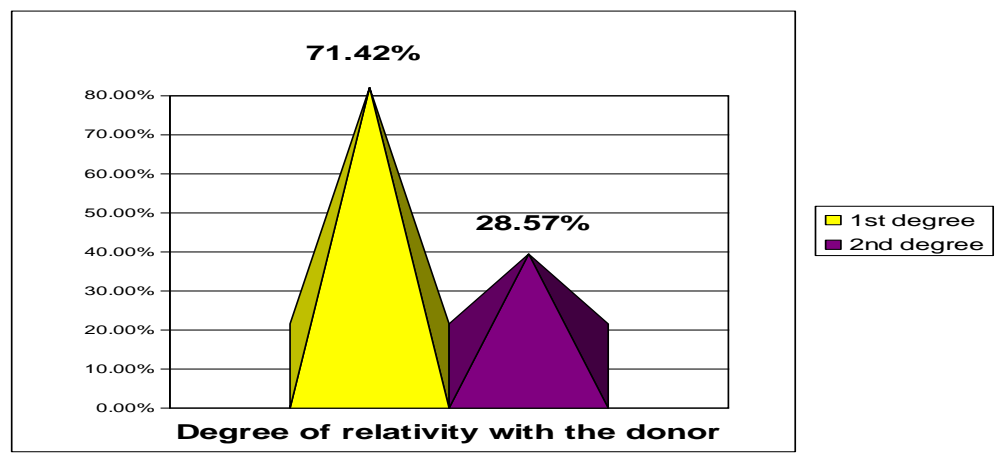

Figure (3): Types of Medications Taken before Transplantation $(\mathrm{n}=11)$ :

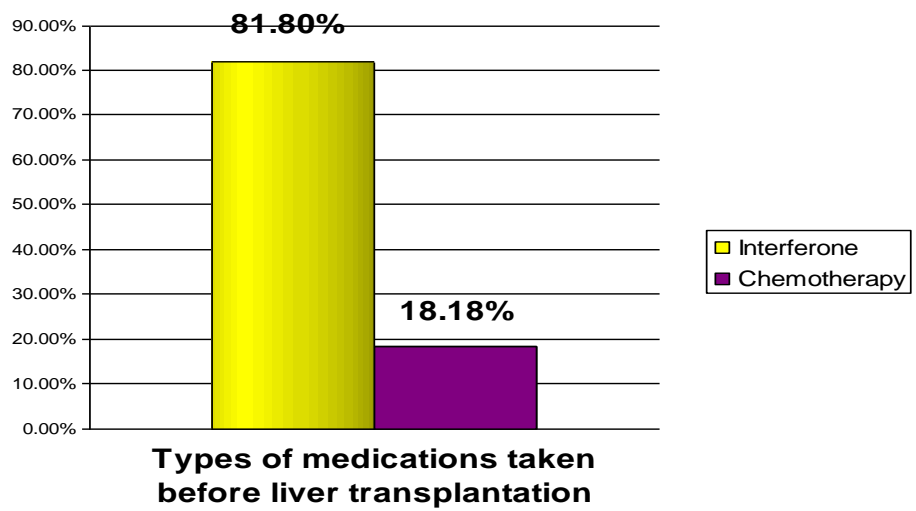

\section{DISCUSSION:}

LT has rapidly advanced from an experimental therapy to a mainstream treatment option for a wide range of acute and chronic liver diseases. Indications for liver transplant have evolved to include previously contraindicated conditions such as hepatocellular carcinoma and alcohol-related liver disease. Cirrhosis from chronic hepatitis $\mathrm{C}$ infection remains the most common indication today (Merion, 2010).

The findings of the present study revealed that, the majority of the studied subjects were in the age group of 40-60 years old with the mean age 49.97 \pm 5.50 . These findings were in 
the accordance with (Hussein, 2012\& Mohammed et al, 2014), who were reported the same result and in accordance with (Wang et al, 2012) who stated that the mean age of their studied subjects was $48.9+8.7$. these results may be due to the chronicity of the disease which is contributed with these age groups this is supported by (Na Li et al, 2015) who emphasized that, cirrhosis is scaring of the liver tissues forms due to injury or long term disease. Regarding to the gender, the present study revealed that the majority of the studied subjects were males. This result was in accordance with (Mabrouk et al, 2012) who found the same result.

Concerning the marital status and educational level, the results of the present study revealed that, the majority of the studied subjects were married and had university education. These findings were supported by the findings of (Chen et al, 2012) who reported that the most of the studied subjects were married and about two thirds were highly educated.

Regarding the studied subjects occupation, more than two thirds of the studied subjects were working. These findings were not similar to the study done by (Aberg et al, 2009) who found that more than two thirds of the studied subjects were not working. The finding of the current study may be due to; all of the study subjects were in the age less than 60 years old. As regarding to residence, the current study revealed that, more than half of the studied subjects were living in rural areas. This result not agreed with (Mendes et al, 2013), who found that, the most of the studied subjects were lived in urban areas.

Concerning the presence of the chronic diseases in between the studied subjects, the results of the present study showed that, less than half of the study subjects had chronic diseases; more than half of them had diabetes mellitus. These findings are in agreement with (Mohamed et al, 2014), who mentioned that about half of the studied subjects had diabetes mellitus.

According to the causes of developing liver failure in between the studied subjects, the result of the current study clarified that the majority of the studied subjects had hepatitis $\mathrm{C}$ as the cause of developing liver failure. This finding was in accordance with (Cuadros et al, 2014), who were stated that Egypt has the highest hepatitis $\mathrm{C}$ virus (HCV) prevalence in the world (14.7\%) and with the reports of $(\boldsymbol{W H O}, 2015) \mathrm{HCV}$ is the most common reason for adult liver transplantation.

Regarding the medications that taken before liver transplantation, the results of the present study stated that, more than quarter of the studied subjects were taken medications before liver transplantation; the majority of them had interferon. This result may be due to most of the studied subjects had past history of HCV. This result was supported by (Chariton et al, 2011), who stated that interferon is strongly predictive of response to antiviral treatment in the non-transplant setting. (Curry et al, 2015), who were stated that, administration of antiviral treatment before transplantation can prevent $\mathrm{HCV}$ recurrence post transplantation.

Concerning the degree of relativity between the recipients and the donors, the results of the current study revealed that more than two thirds of the studied subjects were in the 
first degree in relation with their donors. This showed the family relation between the donor and the recipient on the transplantation outcome. This result is in accordance with (Park et al, 2010), who were found that the majority of his studied subjects donors were from the family members.

As regarding to the family history, the current study showed that more than half of the studied subjects had family history of liver failure the majority of them in first degree relatively, and there was no family history of liver transplantation. This finding may be due to that liver transplantation in Egypt is considered a recent procedure or way of treatment for end stage liver disease. These findings were in the same line with (Mohamed et al, 2014), who were stated that nearly three quarters of the study sample had family history of liver diseases, more than half of them from first degree relatively, as well as most of the study sample hadn't family history of liver transplantation.

Concerning to assess knowledge of liver transplant patients, the results of current study revealed that the presence of statistically significant difference throughout the study periods as compared to their pre-implementation score. The rational of knowledge improvement among the study group subjects throughout the different assessment periods may be as a result of the provision and explanation of the instructional scheme. These results in accordance with (Delar et al, 2010) who were reported that the candidates exposed to peer-based intervention reported significantly greater knowledge. Greater likelihood of discussing donation and increased self-efficacy in comparison with those not exposed to the intervention. Moreover, Mendes et al, 2013 stated that in the analysis of the correct answers to the questions in the knowledge assessment instrument on the transplantation process before and after the educational intervention a statistically significant difference is observed $(\mathrm{P}=0.0043)$.

As regarding to assess the practice of liver transplant recipients, the results of the current study delineated that, the presence of statistical and highly statistical significant differences throughout the study periods among the study subjects as compared to their pre- implementation score. The rational of practice improvements among the study subjects throughout the assessment periods may be a result of the provision of direct demonstration, re-demonstration, and follow- up of practical content in instructional scheme which was given to the study subjects.

This result was in accordance with (Basha et al, 2015\& Didsbury et al, 2013), who were revealed that presence of a significant decrease in fat mass, cholesterol and triglyceride levels in the exercise group compared to the control group $(p<0.001)$, while there was a significant increase in muscle mass in the exercise group compared to control group ( $p=0.0001)$ after liver transplantation. Similarly (Roi et al, 2014), who were performed exercises consisting of 3 sessions per week of aerobic and strengthening exercises for 1 year on 5 patients with liver transplantations. Patients showed a significant decrease in body mass index $(t=1.966 ; p<.05)$ and a maximum strength of knee extensors $(t=2.933 ; p<.05)$ and elbow flexors $(t=2.450 ; p<.05)$. These results were confirmed the positive effects of supervised physical exercise. 
Also, Garcia et al, 2014 were concluded that the exercise program promoted significant improvements in functional capacity. These findings have positive implications for the control of metabolic diseases, which are common in patients after liver transplantation.

\section{CONCLUSION:}

Based on study findings, it can be concluded that: Liver transplantation patients showed an improvement in their knowledge and practice scores of different breathing, coughing\& using spirometer, and range of motion exercises. This improvement was manifested in their immediately and after instructional scheme implementation total and subtotal mean knowledge and practice scores.

\section{RECOMMENDATIONS:}

All patients are scheduled for liver transplantation and their families are in the need to an adequate knowledge to help them to adapt with their life after transplantation. Establishment of a web site, including all information pertained to transplantation process and all aspects of health education such as different educational materials, Medias, and audio- visual aids. National strategies are highly required to support liver transplantation patients and their families. Replication of the study on a large probability sample selected from different geographical areas to obtain generalized data.

\section{REFERENCES:}

Abd El-Wahab, M., Gad- El hak, A., N., El shobary, M., M., et al. (2012): Living Donor Liver Transplantation: Retrospective and Prospective study, UN published thesis, Doctoral degree, Faculty of Medicine, Mansoura University, Egypt.

Abd El- Hakeem, A., A. (2014): Preoperative Evaluation for Living Donor Liver Transplantation. From the web: WWW. Slide share.net, Retrieved on July 21, 2015.

Aberg, F., Rissanen, A., Sintonen, H., et al. (2009): Health-Related Quality of Life and Employment Status of Liver Transplant Patients. Liver Transplantation; vol. (15): Pp. 6472.

Abou-Shehata, E., M., Hatata, Z., E., Shebl, M., A .; and Fadila, M., D. (2012): Effect of a Pulmonary Rehabilitation Program on the Quality of Life of Elderly Patients with Chronic Obstructive Pulmonary Disease, published thesis for Doctoral degree in Nursing Science, Geriatric Nursing, Faculty of Nursing, Mansoura university, Egypt.

Amer, K., E and Marwan, I, (2016): Living Donor Liver Transplantation in Egypt. Hepatobiliary Surgery and Nutrition; 5 (2): Pp. 98-106.

Basha, A., M., Mowafy, E., Z.; and Morsy, A., E. (2015): Sarcopenic obesity and dyslipidemia response to selective exercise program after liver transplantation, Egyptian Journal of Medical Human Genetics; Vol. 16 (3): Pp. 263-268. 
Busuttil, W., R.; and Klintmalm, G., G. (2015): Transplantation of the Liver, 3rd ed, P: 719, Elsevier, Saunders, America.

Chariton, M., R., Thompson, A., Veldt, B., et al. (2011): Interleukin- 28 B polymorphisms are associated with Histological Recurrence and Treatment Response Following Liver Transplantation in Patients with Hepatitis C virus Infection, Hepatology; vol. 53 (1): Pp.317-24.

Chen, P., Yan, L.; and Wang, W. (2012): Health-Related Quality of Life of 256 Recipients after Liver Transplantation. World J Gastroenterol; vol. 18(36): Pp. 5114-21.

Cuadros, D., F., Branscum, A., J., Miller, F., D.; and Abu-Raddad, L., J. (2014): Spatial epidemiology of Hepatitis $C$ virus Infection in Egypt: analyses and Implications, Hepatology; vol. 60 (4). Pp. 1150-9.

Curry, M., P., Forns, X., Chung, R., T., et al. (2015): Sofosbuvir and Ribavirin Prevent Recurrence of HCV infection after Liver Transplantation: an open- labed study, Gastroenterology; vol. 148 (1). Pp. 100-107.

Delar, et al. (2010):Apeer- based Intervention to Educate Liver Transplant Candidates about Living Donor Liver Transplantation. Liver Transplantation Journal; vol. (16): 4248.

Didsbury, R., G., McGee, A., Tong, J., C.,et al. (2013): Exercise training in solid organ transplant recipients: a systematic review and meta-analysis, Transplantation; vol. 95 (5): pp. 679-687.

Duma, E. (2012): Liver transplantation. Nurs Stand;vol: 26(41), pp.59-60.

El-Gamal, M., S., Morsy, M., W., Ismail, S., M.; and El-Shazly, A., M. (2013) :Impact of a Designed Nursing Intervention Protocol about Preoperative Liver Transplantation Care on Patients' Outcomes at a University Hospital in Egypt, Journal of Education and Practice; Vol. 19 (4): Pp.105-116.

Garcia, M., A., Veneroso, E., C., Soares, D., D., et al. (2014): Effect of a physical exercise program on the functional capacity of liver transplant patients, Transplant Proc; vol. 46 (6): Pp. 1807-1808.

Hussein, D., H. (2012): Assessment of Functional Health Status among Patients with Liver Transplantation at Dar El Fouad Hospital. Unpublished Thesis Submitted for partial fulfillment of Master Degree in Nursing Science. Faculty of Nursing. Cairo University, Egypt.

Kaltsakas, Antoniou, E., Palamidas, F., A., et al. (2013): Dyspnea and Respiratory Muscle Strength in end- stage Liver Disease. World Journal of Hepatology; Vol. 5, (2): Pp.56-62. 
Kruzik, N. (2009): Benefits of preoperative education for adult elective surgery patients. AORN J; vol.90 (3):Pp.381-7.

Mabrouk, M., Esmat, G., Yosry, A.,et al. (2012): Health Related Quality of Life in Egyptian Patients after Liver Transplantation.Annals of hepatology; official journal of the Mexican Association of Hepatology; vol. 11(6): Pp. 882-90.

Marwan, I., Ibrahim, T.; and Tanaka, K. (2012): Ten Years of LDLT: Outcome Data from the Egyptian Liver Transplantation Registry. (Quoted) from a presentation by prof. Ibrahim Marwan at Egyptian Society of surgeon's conference, Port Said, Egypt, April 2012.

Mendes, K., Castro e Silva, O., Ziviani, L., C., et al. (2013): Educational Intervention for Liver Transplantation Candidates. Latino-Am. Enfermagem; vol: 21(1): Pp. 419-25.

Mendes, K.; and Galvão, C. (2008): Liver Transplantation: Evidence for Nursing Care. Latino-am Enfermagem; 16(5): Pp.915-22.

Merion, M., R. (2010): Current Status and Future of Liver Transplantation, Seminars in Liver Disease 2010; vol.30(4): 411-421, From the Web: https://www. thieme-connect .com /products /ejournals /abstract /10 . 1055/s-0030-1267541.

Mohammed, A., M., Ali, A., M., Abd-El-Razik, G., B.; and Mohammed, G., Z. (2014): Health Related Quality of Life for Patients with Liver Transplantation, thesis for Master Degree in Nursing Science, Adult Nursing, Faculty of Nursing, Port Said University, Egypt.

Na Li, Kirkpatrick, R.; and Michaels, A. (2015): Ohio State Specialists Provide Personalized Care for Cirrhosis and other Chronic Liver Diseases.

Park, J., S., Suklim, Y., Hwang, S., et al. (2010): Emergency Adult- to- Adult LivingDonor Liver Transplantation for Acute Liver Failure in a Hepatitis B Virus Endemic Area, Hematology 51, (3).

Roi, G., S., Stefoni, G., Mosconi, E., et al. (2014): Physical activity in solid organ transplant recipients: organizational aspects and preliminary results of the Italian project, Transplant Proc. 46 (7), pp. 2345-2349.

Smeltzer, S., O., Hinkle, J., L.; and Bare, B., G. (2010): Brunner \& Suddarth's Text book of Medical Surgical Nursing, $1^{\text {st }}$ ed, chapter: 27.Pp. 1163, 1149, Wolters Klumer Health Amazon. Com.

Wang, G., Yang, Y., Li, H., et al. (2012): Health-Related Quality of Life after Liver Transplantation: The Experience from a Single Chinese Center. Hepatobiliary Pancreat Dis Int; vol.11 (3): Pp. 262-6. 


\section{تأثير خطة تعليمية للمرضي الخاضعين لجراحة زراعة الكبد علي أدائهم}

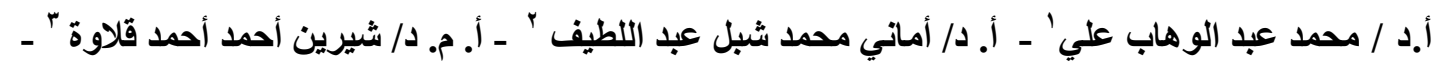

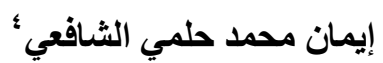 \\ ' أستاذ جر/حة الجهاز الهضدي ـ كلبة الطب - جامعة المنصورة / ' أستاذ التصريض الباطني الجراحي - عبيد كلية

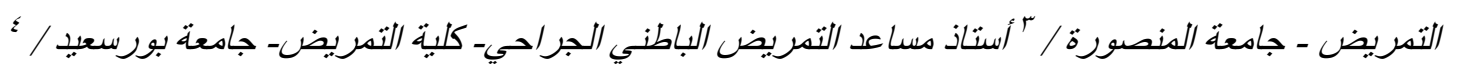 \\ أخصائيتمريض - جامعة المنصورة.}

\section{الخلاصة}

تعتبر زراعه الكبد العلاج الذهبي الحسالي لعلاج مرضي الفشل الكبدي الحساد، المزمن، وأورام الكبد المبكرة. وتقوم عمليه زر اعة الكبد بتحسين جودة حياة هؤ لاء المرضي. كان الهدف من هذه الدر اسة تقييم تأثير خطه تعليمية للمرضي ولئي الخاضعين لجر احة زر اعة الكبد علي نتائجهم الصحية. تم عمل در اسـة شبه تجريبية مـع تقيم قبلي وبعدي في هذه هـه

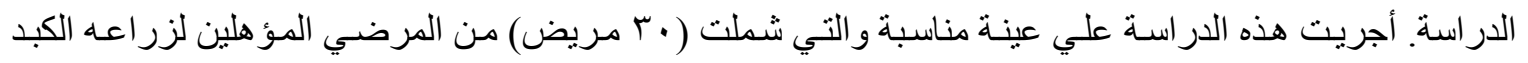

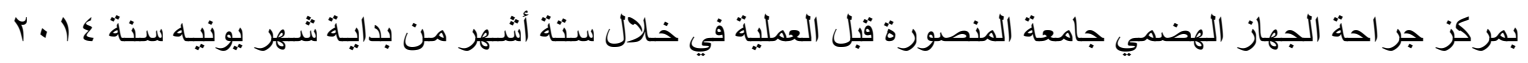

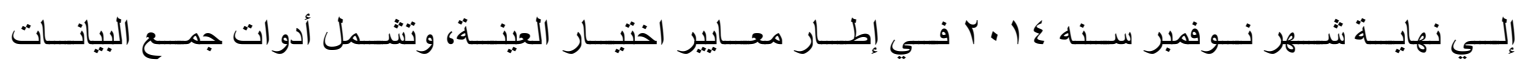

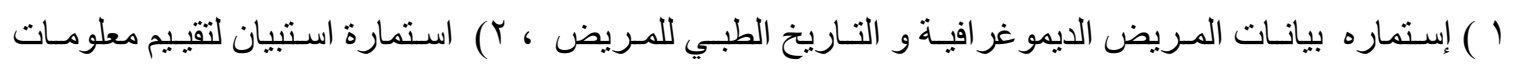

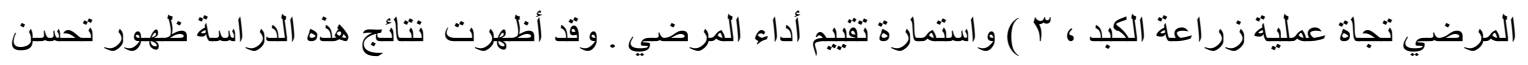

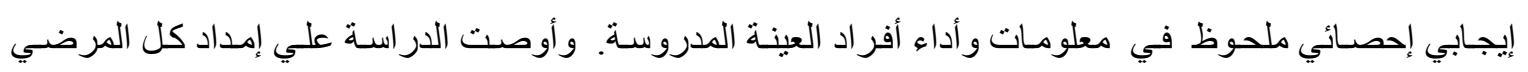

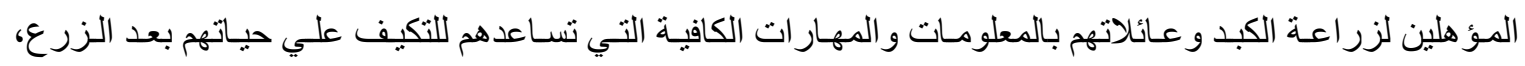
وتطبيق نفس الدراسة علي عينة أكبر مختارة من نوزيع جغر افي أخر للحصول علي معلومات أوسع وأثمل.

الكلمات المرشدة : زراعة الكبد، أدائهم، و خطة تعليمبة 